\title{
Upaya Peningkatan Pendidikan Karakter pada Pembelajaran Fisika Menggunakan Model POE2WE
}

\author{
Mutia Laelawati ${ }^{*}$ Nana $^{2}$ \\ ${ }^{1}$ Mahasiswa Program Studi Pendidikan Fisika, Universitas Siliwangi \\ ${ }^{2}$ Dosen Program Studi Pendidikan Fisika, Universitas Siliwangi \\ *email: mutialaelawati55@gmail.com
}

\begin{abstract}
Increasing character education in physics learning using the poe 2 we model aims to (1) improve character education in physics learning (2) applying the poe2we model in physics learning (3) improve character education in physics pursuits using the poe2we model. The research method used is literacy (literature study). Character education is education that is able to increase the ability of students to deal with circumstances or make good and bad decisions in life, these character values can be integrated in physics learning, one of which is through the POE2WE learning model.
\end{abstract}

Keywords: POE2WE Model, Character Education

\begin{abstract}
Abstrak: peningkatan pendidikan karakter pada pembelajaran fisika menggunakan model poe2we bertujuan untuk (1) meningkatkan pendidikan karakter pada pembelajaran fisika (2) menerapkan model poe2we pada pembelajaran fisika (3) meningkatkan pendidikan karakter pada pembejaran fisika menggunakan model poe2we. Metode penelitian yang digunakan adalah literasi (studi pustaka). Pendidikan karakter merupakan pendidikan yang mampu meningkatan kemampuan siswa dalam menghadapi suatu keadaan atau mengambil keputusan baik buruknya didalam kehidupan, nilai-nilai karakter tersebut dapat diintegrasikan dalam pembelajaran fisika, salah satunya melalui model pembelajaran POE2WE.
\end{abstract}

Kata kunci: Model POE2WE, Pendidikan Karakter

\section{PENDAHULUAN}

Pada zaman sekarang ini apabila kita perhatikan dengan seksama, terjadi perubahan karakter bangsa yang luar biasa pada diri orang dewasa maupun anak-anak. Khusus para siswa yang duduk di bangku sekolah, krisis tersebut diantaranya kebocoran kunci jawaban pada saat ujian nasional (UN) atau contek massal yang terjadi di beberapa daerah di Indonesia seperti di daerah DI Yogyakarta, Aceh Utara, Bekasi, Probolinggo, Bengkulu, dan Lampung Tengah (Indra, 2011), kekerasan di kalangan remaja yang semakin memprihatinkan. Sebagai contoh, aksi premanisme yang dilakukan oleh para pelajar, kebiasaan menyontek, tawuran, bahkan sampai maraknya bullying (Pulungan, 2012)

Penurunan perilaku di atas yang sedang dihadapi para pelajar saat ini sangat mengkhawatirkan, terlebih setelah dilakukan survey dan investigasi terhadap perilaku siswa dalam jangka waktu setahun oleh The Ethics of American Youth, dari Josepshon Institutes of Ethics, yaitu: sekitar $82 \%$ mengakui bahwa mereka berbohong kepada orang tua; 62\% mengakui bahwa mereka berbohong kepada guru perihal sesuatu yang signifikan; 33\% menjiplak atau disebut plagiat dari internet; $60 \%$ menipu dissat melaksanakan ujian di sekolah; 23\% mencuri sesuatu dari seorang teman; dan $28 \%$ mencuri sesuatu dari toko (Pulungan, 2012) 
Menurut Pulungan (dalam Zubaedi, 2011) ia menyebutkan bahwa Menurut Komnas Perlindungan Anak, tidak terjadinya perubahan perilaku siswa dikarenakan tiga hal, antara lain:

1) Kurikulum yang berlaku di sekolah saat ini lebih mengutamakan pada peningkatan prestasi akademik pelajar daripada ekspresi diri. Akibatnya, kebutuhan anak untuk mengekspresikan diri tidak tersalurkan dengan baik dan cenderung salah arah. Salah satunya melalui aksi tawuran.

2) Kurangnya sosialisasi dan edukasi tentang karakter pelajar yang sesuai, baik di sekolah maupun lingkungan rumah, seperti karakter berani bertanggung jawab atas perilaku dan tindakan, jujur, toleransi dengan sesama maupun menghargai pluralisme yang ada di sekitarnya.

3) Berdasarkan hasil analisis pemetaan fakta di lapangan diketahui bahwa sebagian besar aksi tawuran yang ada di Indonesia terjadi karena budaya atau kebiasaan di lingkungan sekolah masing-masing. Kesimpulan itu didapatkan dari fakta bahwa mayoritas pelajar yang terlibat masih menduduki tingkat pertama atau kedua.

Menurut Pulungan (dalam Wu Jian (2004)) pembelajaran Fisika di kelas merupakan kesalahan bagi sebagian siswa karena siswa merasa tidak relevan, membosankan, merasa susah dan tidak berguna di dunia nyata. Siswa tidak salah dalam menyampaikan pendapat tersebut, namun seorang guru harus melihat dan mendengar juga merubah metode pengajaran agar keadaan seperti ini bisa diatasi.

Salah satu metode pengajaran yang disarankan adalah model POE2WE (Prediction, Observation, Explanation, Elaboration, Write and Evaluation). Model POE2WE merupakan model pembelajaran Student Center Learning (SCL) atau pembelajaran yang menekankan pada keaktifan dari peserta didik dalam melakukan kegiatan pembelajaran. Model POE2WE dipilih karena selain memaksimalkan keaktifan dari peserta didik, model ini pun sejalan dengan pembelajaran abad 21, yaitu Creative, Critical Thinking, Communicative, dan Colaborative. Menurut Nana, dkk (2014) sintaks model pembelajaran POE2WE adalah memprediksi, membahas, menjelaskan, menguraikan, menulis, dan mengevaluasi.

\section{METODE PENELITIAN}

Penelitian ini menggunakan metode literasi (studi pustaka) dengan cara mengkaji berbagai literatur yang berkaitan dengan pendidikan karakter dan penerapan model POE2WE pada pembelajaran fisika. (Diani, Rahmi. (2015); Duffy, T. M., \& Jonassen, D. H. (1992); Indra. (2011); Komara, Endang. (2018); Nana. (2014); Nana \&Surahman, E. (2019); Pulungan, Fatma Reni. (2012); Samosir, H. (2010); Zuchdi, Darmiyati., Anik Ghufron.,Kastam Syamsi., \& Muhsinatun Siasah Masruri. (2014). Model POE2WE merupakan model yang sebelumnya telah dikembangkan oleh Nana, Sajidan, Akhyar, \& Rochsatiningsih (2014) dari model POEW (Samosir, 2010) dan pembelajaran Fisika dengan pendekatan konstruktivis (Duffy \& Jonassen, 1992). 


\section{HASIL PENELITIAN DAN PEMBAHASAN}

\subsection{Pendidikan Karakter}

Menurut Komara (dalam Koesoema, 2007; Muslich, 2011; dan Zainal, 2011) Pendidikan karakter merupakan suatu keniscayaan dalam upaya menghadapi berbagai tantangan pergeseran karakter yang dihadapi saat ini. Pendidikan karakter bertujuan mengembangkan kemampuan seseorang untuk memberikan keputusan baik-buruk, memelihara apa yang baik, dan mewujudkan kebaikan itu dalam kehidupan sehari-hari dengan sepenuh hati.

Dalam konteks ini, peran sekolah sebagai communities of character dalam pendidikan karakter sangat penting. Sekolah mengembangkan proses pendidikan karakter melalui proses pembelajaran, habituasi, kegiatan ekstra-kurikuler, dan bekerja sama dengan keluarga dan masyarakat dalam pengembangannya (Komara, 2018)

Menurut Komara (dalam Kemendiknas RI, 2010a dan 2010b; Asmani, 2011; dan Komalasari \& Saripudin, 2017) Gerakan PPK (Penguatan Pendidikan Karakter), yang dicanangkan oleh Kementerian Pendidikan dan Kebudayaan Republik Indonesia pada tahun 2017,1 mengidentifikasi lima nilai utama karakter yang saling berkaitan dalam membentuk jejaring nilai yang perlu dikembangkan sebagai prioritas, yaitu: nilai religius, nasionalis, mandiri, gotong-royong, dan integritas.

Menurut Diani (dalam Gunawan (2012:28)) menyebutkan bahwa, pendidikan karakter merupakan upaya-upaya yang dirancang dan dilaksanakan secara sistematis untuk menanamkan nilai-nilai perilaku peserta didik yang berhubungan dengan Tuhan Yang Maha Esa, diri sendiri, sesama manusia, lingkungan, dan kebangsaan yang terwujud dalam pikiran, sikap, perasaan, perkataan, dan perbuatan berdasarkan norma-norma agama, hukum, tata karma, budaya, dan adat istiadat. Berdasarkan penjelasan ini, pendidikan karakter dapat diyakini sebagai aspek penting dalam pendidikan terutama dalam upaya peningkatan Sumber Daya Manusia (SDM).

Menurut Zuchdi, dkk. ( dalam Triatmanto, 2010 Masruri) Pendidikan karakter adalah suatu sistem penanaman nilai-nilai karakter kepada warga sekolah yang meliputi komponen pengetahuan, kesadaran atau kemauan, dan tindakan untuk melaksanakan nilai-nilai tersebut, baik terhadap Tuhan Yang Maha Esa (YME), diri sendiri, sesama, lingkungan, maupun kebangsaan sehingga menjadi manusia insan kamil. Selain itu, Menurut Darmiyati, dkk. dalam Prasetya \& Rivashinta, 2011) Dalam pendidikan karakter di sekolah, semua komponen pendidikan (stakeholders) harus dilibatkan, termasuk komponen-komponen pendidikan itu sendiri, yaitu isi kurikulum, proses pembelajaran dan penilaian, kualitas hubungan, penanganan atau pengelolaan mata pelajaran, pengelolaan sekolah, pelaksanaan aktivitas, pemberdayaan sarana prasarana, pembiayaan, dan etos kerja seluruh warga dan lingkungan sekolah. Seseorang dikatakan berkarakter jika telah berhasil menyerap nilai dan keyakinan [baik] yang dikehendaki masyarakat serta digunakan sebagai kekuatan moral dalam hidupnya. Pendidikan karakter dapat diintegrasikan ke dalam pembelajaran pada setiap mata pelajaran. 
Materi pembelajaran yang berkaitan dengan norma atau nilai-nilai pada setiap mata pelajaran perlu dikembangkan, dieksplisitkan, dan dikaitkan dengan konteks kehidupan sehari-hari. Dengan demikian, pembelajaran nilai-nilai karakter tidak hanya pada tataran kognitif, tetapi menyentuh pada internalisasi, dan pengamalan nyata dalam kehidupan siswa sehari-hari di masyarakat. Dalam hal pemilihan nilai-nilai target pendidikan karakter, 66,7\% guru SMP dan 100\% guru SMA menyatakan ditentukan oleh sekolah sendiri dan terkandung dalam visi dan misi sekolah. Adapun nilai-nilai tersebut menurut 83,3\% guru SMP dan 96\% guru SMA meliputi nilai-nilai prioritas nasional, yaitu jujur, cerdas, tangguh, dan peduli. Namun berdasarkan hasil analisis RPP, nilai-nilai yang dikembangkan di SMP kebanyakan adalah dapat dipercaya, rasa hormat, tekun, kerja sama, dan bertanggung jawab, sedangkan untuk SMA nilai terampil, kerja keras, rasa ingin tahu, komunikatif, cermat, teliti, kooperatif, kolaboratif, dan menghargai prestasi. Dengan kata lain tidak ada sekolah yang memilih nilai target jujur. Adanya perbedaan informasi ini perlu digali lebih dalam melalui wawancara dan pengamatan. (Zuchdi et al. 2014).

Pendidikan karakter merupakan pendidikan nilai, budi pekerti, moral, dan watak, yang bertujuan untuk mengembangkan kemampuan siswa dalam memberikan keputusan baik dan buruk, memelihara apa yang baik, dan mewujudkan kebaikan itu dalam kehidupan sehari-hari dengan sepenuh hati. Pendidikan karakter yang baik harus melibatkan bukan saja aspek pengetahuan yang baik (moral knowing), tetapi juga merasakan dengan baik atau loving the good and moral feeling, serta perilaku yang baik (moral action). Jadi, pendidikan karakter erat kaitannya dengan habit atau kebiasaan, yang terus-menerus dipraktikkan dan dilakukan. Pendidikan karakter merupakan suatu kebiasaan, maka pembentukan karakter seseorang itu memerlukan communities of character, yang terdiri atas keluarga, sekolah, institusi keagamaan, media, pemerintahan, dan berbagai pihak yang mempengaruhi generasi muda. Semua communities of character tersebut hendaknya memberikan suatu keteladanan, intervensi, serta pembiasaan, yang dilakukan secara konsisten dan penguatan. Dengan kata lain, pembentukan karakter memerlukan pengembangan keteladanan yang ditularkan dan intervensi melalui proses pembelajaran, pelatihan, dan pembiasaan yang terus-menerus dalam jangka panjang. Pendidikan nasional di abad ke-21 bertujuan untuk mewujudkan cita-cita bangsa, yaitu masyarakat bangsa Indonesia yang sejahtera dan bahagia, dengan kedudukan terhormat dan setara dengan bangsa-bangsa lain di tingkat global. Citacita tersebut bisa diwujudkan melalui pembentukan masyarakat yang terdiri dari sumber daya manusia yang berkualitas, yaitu pribadi yang mandiri, berkemauan, dan berkemampuan untuk mewujudkan cita-cita bangsanya. Mengenai pengembangan pembelajaran di abad ke-21, beberapa hal yang perlu diperhatikan, antara lain: tugas utama guru sebagai perencana pembelajaran, memasukkan unsur berpikir tingkat tinggi atau higher order thinking, penerapan pola pendekatan dan model pembelajaran yang bervariasi, serta integrasi teknologi. (Komara, 2018)

\subsection{Model POE $\mathrm{PE}_{2}$}

Model pembelajaran Prediction, Observation, Explanation, Elaboration, Write dan Evaluation $\left(\mathrm{POE}_{2} \mathrm{WE}\right)$ dikembangkan dari model pembelajaran POEW dan model pembelajaran Fisika dengan Pendekatan Konstruktivistik. Pengembangan ini dilakukan untuk sebagai penyempurnaan kedua model sebelumnya. Model $\mathrm{POE}_{2} \mathrm{WE}$ merupakan model pembelajaran yang dikembangkan untuk mengetahui pemahaman peserta didik mengenai 
suatu konsep dengan pendekatan konstruktivistik. Model ini membangun pengetahuan dengan urutan proses yaitu meramalkan atau memprediksi solusi dari permasalahan, melakukan eksperimen untuk membuktikan prediksi, kemudian menjelaskan hasil eksperimen yang diperoleh secara lisan maupun tertulis, membuat contoh penerapan dalam kehidupan seharihari, menuliskan hasil diskusi dan memuat evaluasi tentang pemahaman peserta didik baik secara lisan maupun tertulis. (Nana, 2014, 2016; Nana et al., 2014; Nana dan Surahman, 2019, 2020; Permatasari, 2011; Rahayu et al.,2013; Samosir, 2010)

Penggabungan tahapan-tahapan pembelajaran model POEW dan model pembelajaran Fisika dengan Pendekatan Konstruktivistik maka dapat di susun langkah-langkah pembelajaran model $\mathrm{POE}_{2} \mathrm{WE}$ secara terinci sebagai berikut:

\section{a) Prediction}

Tahap prediction yaitu peserta didik membuat prediksi atau dugaan awal terhadap suatu permasalahan. Permasalahan yang ditemukan berasal dari pertanyaan dan gambar tentang materi yang disampaikan oleh guru yang ada di Lembar Kerja peserta didik (LKS)/buku peserta didik sebelum peserta didik membuat prediksi. Pembuatan prediksi jawaban tahap Prediction pada model POEW identik dengan fase Engagenent pada pendekatan konstruktivistik. Guru mengajukan pertanyaan yang dapat mendorong peserta didik untuk dapat membuat prediksi atau jawaban sementara dari suatu permasalahan. b) Observation Tahap Observation yaitu untuk membuktikan prediksi yang telah di buat oleh peserta didik. Peserta didik diajak melakukan eksperimen berkaitan dengan masalah atau persoalan yang di temukan. Selanjutnya peserta didik mengamati apa yang terjadi, kemudian peserta didik menguji kebenaran dari dugaan sementara yang telah dibuat. Tahap Observation pada model POEW identik dengan fase Exploration pada pendekatan konstruktivistik.

c) Explanation

Tahap Explanation atau menjelaskan yaitu peserta didik memberikan penjelasan terhadap hasil eksperimen yang telah dilakukan. Penjelasan dari peserta didik dilakukan melalui diskusi dengan anggota kelompok kemudian tiap kelompok mempresentasikan hasil diskusinya di depan kelas. Jika prediksi yang di buat peserta didik ternyata terjadi di dalam eksperimen, maka guru membimbing peserta didik merangkum dan memberi penjelasan untuk menguatkan hasil eksperimen yang dilakukan. Namun jika prediksi peserta didik tidak terjadi dalam eksperimen, maka guru membantu peserta didik mencari penjelasan mengapa prediksi atau dugaannya tidak benar. Tahap explanation identik dengan fase explanation pada pendekatan konstuktivistik.

d) Elaboration

Tahap elaboration yaitu peserta didik membuat contoh atau menerapkan konsep dalam kehidupan sehari-hari. Tahap elaboration di ambil dari pendekatan konstruktivistik. Tahap ini guru mendorong peserta didik untuk menerapkan konsep baru dalam situasi baru sehingga peserta didik lebih memahami konsep yang di ajarkan guru. Tahap ini pengembangan dari pendekatan konstruktivistik.

e) Write

Tahap write atau menulis yaitu melakukan komunikasi secara tertulis, merefleksikan pengetahuan dan gagasan yang dimiliki peserta didik Menurut Masingilia dan Wisniowska (1996) dalam (Yamin \& Ansari, 2012) menulis dapat membantu peserta didik untuk mengekspresikan pengetahuan dan gagasan mereka. peserta didik menuliskan hasil diskusi dan menjawab pertanyaan yang ada pada LKS. Selain itu pada tahap write 
ini, peserta didik membuat kesimpulan dan laporan dari hasil eksperimen. Tahap ini merupakan pengembangan dari model TTW.

f) Evaluation

Tahap Evaluation yaitu evaluasi terhadap pengetahuan, keterampilan dan perubahan proses berpikir peserta didik. Pada tahap ini peserta didik di evaluasi tentang materi gerak lurus berupa lisan maupun tulisan. Tahap ini merupakan pengembangan dari pendekatan konstruktivistik.

Penggabungan tahap-tahap model POEW dan pendekatan konstruktivistik dapat di lihat pada Tabel 1 dan 2.

Tabel 1. Sintaks Pengembangan model $\mathrm{POE}_{2} \mathrm{WE}$

\begin{tabular}{|c|c|c|c|}
\hline No. & Sintaks POEW & $\begin{array}{l}\text { Sintaks model Pembelajara } \\
\text { dengan Pendekatan } \\
\text { Konstruktivistik }\end{array}$ & n Model $\mathrm{POE}_{2} \mathrm{WE}$ \\
\hline 1. & $\begin{array}{l}\text { (Prediction) membuat } \\
\text { prediksi, membuat } \\
\text { dugaan }\end{array}$ & $\begin{array}{l}\text { (Engagement) pendahuluan } \\
\text { membuat pertanyaan } \\
\text { menggali pengetahuan awal } \\
\text { peserta didik. }\end{array}$ & $\begin{array}{l}\text { (Prediction) } \\
\text { Membuat dugaan atau prediksi. } \\
\text { Tahap Engagement identik } \\
\text { dengan Predict pada POEW }\end{array}$ \\
\hline 2. & $\begin{array}{l}\text { (Observation) } \\
\text { Melakukan penelitian, } \\
\text { pengamatan }\end{array}$ & $\begin{array}{l}\text { (Exploration) menguji } \\
\text { prediksi ,melakukan dan } \\
\text { mencatat hasil pengamatan. }\end{array}$ & $\begin{array}{l}\text { (Observation) Melakukan } \\
\text { observasi/pengamatan Tahap } \\
\text { Exploration identik dengan } \\
\text { tahap observation pada } \\
\text { POEW. }\end{array}$ \\
\hline 3. & $\begin{array}{l}\text { (Explanation) } \\
\text { Yaitu } \\
\text { penjelasan }\end{array}$ & $\begin{array}{l}\text { (Explation) menjelaskan } \\
\text { konsep dengan kalimat } \\
\text { mereka sendiri }\end{array}$ & $\begin{array}{l}\text { (Explanation) } \\
\text { Menjelaskan Pada tahap } \\
\text { explanation identik dengan } \\
\text { explation pada pendekatan } \\
\text { konstruktivistik }\end{array}$ \\
\hline 4. & $\begin{array}{l}\text { (Write) } \\
\text { Membuat kesimpulan }\end{array}$ & $\begin{array}{l}(\text { Elaboration) } \\
\text { Aplikasi } \quad \text { konsep } \\
\text { dalam kehidupan } \\
\text { sehari-hari. }\end{array}$ & $\begin{array}{l}\text { (Elaboration) } \\
\text { Aplikasi konsep dalam } \\
\text { kehidupan sehari-hari } \\
\text { merupakan pengembangan } \\
\text { dari pendekatan } \\
\text { Konstruktivistik } \\
\end{array}$ \\
\hline 5. & & $\begin{array}{l}\text { (Evaluation) Evaluasi } \\
\text { terhadap pengetahuan, } \\
\text { keterampilan dan } \\
\text { perubahan proses berpikir } \\
\text { peserta didik. }\end{array}$ & $\begin{array}{ll}\text { (Write) } & \\
\text { Menuliskan } & \text { hasil diskusi } \\
\text { sebagai } & \text { kesimpulan. } \\
\text { Merupakan } & \text { pengembangan } \\
\text { dari model POEW }\end{array}$ \\
\hline
\end{tabular}




\begin{tabular}{|l|l|l|}
\hline 6. & & (Evaluation) \\
& & Evaluasi terhadap efektivitas \\
& & fase-fase sebelumnya. \\
& & Merupakan pengembangan \\
& dari pendekatan \\
& Konstruktivistik \\
\hline
\end{tabular}

Tabel 2. Kegiatan pembelajaran Model Pembelajaran Model $\mathrm{POE}_{2} \mathrm{WE}$

\begin{tabular}{|c|c|c|c|c|}
\hline Fase- fase & & \multicolumn{2}{|l|}{ Kegiatan Guru } & Kegiatan Peserta Didik \\
\hline Prediction & & $\begin{array}{l}\text { Menyampaikan tujuan } \\
\text { pembelajaran. } \\
\text { Mengajukan pertanyaan kepada } \\
\text { siswa } \\
\text { Menginventarisi prediksi dan - alasar } \\
\text { yang di kemukakan peserta didik. }\end{array}$ & - & $\begin{array}{l}\text { Memperhatikan penjelasan } \\
\text { dari guru. } \\
\text { Memprediksi jawaban } \\
\text { pertanyaan dari guru } \\
\text { Mendiskusikan hasil } \\
\text { prediksinya }\end{array}$ \\
\hline Observation & & $\begin{array}{l}\text { Mendorong peserta didik untuk } \\
\text { bekerja secara kelompok - } \\
\text { Membagikan LKS } \\
\text { Mengawasi kegiatan percobaan yang } \\
\text { dilakukan oleh peserta didik - }\end{array}$ & - & $\begin{array}{l}\text { Membentuk kelompok } \\
\text { Melakukan percobaan } \\
\text { Mengumpulkan data hasil } \\
\text { percobaan } \\
\text { Melakukan diskusi kelompok }\end{array}$ \\
\hline & & & & $\begin{array}{l}\text { Menyimpulkan hasil } \\
\text { percobaan }\end{array}$ \\
\hline Explanation & & $\begin{array}{l}\text { Mendorong peserta didik untuk } \\
\text { menjelaskan hasil percobaan. } \\
\text { Meminta peserta didik } \\
\text { mempresentasikan hasil } \\
\text { percobaannya } \\
\text { Mengklarifikasikan hasil } \\
\text { percobaannya } \\
\text { Menjelaskan konsep/definisi baru }\end{array}$ & - & $\begin{array}{l}\text { Mengemukakan pendapatnya } \\
\text { tentang hasil percobaan } \\
\text { Mengemukakan pendapatnya } \\
\text { tentang gagasan baru } \\
\text { berdasarkan hasil percobaan. } \\
\text { Menanggapi presentasi dari } \\
\text { kelompok lain. } \\
\text { Konsep baru dari guru dapat } \\
\text { di terima }\end{array}$ \\
\hline Elaboration & - & $\begin{array}{l}\text { Memberi permasalahan berkaitan } \\
\text { dengan penerapan konsep. Mendoror } \\
\text { peserta didik untuk menerapkan kons } \\
\text { baru dalam situasi baru. }\end{array}$ & & $\begin{array}{l}\text { Menerapkan konsep baru } \\
\text { dalam situasi baru atau } \\
\text { kehidupan sehari-hari. }\end{array}$ \\
\hline
\end{tabular}




\begin{tabular}{|c|c|c|}
\hline Write & $\begin{array}{l}\text { - Memberi kesempatan kepada } \\
\text { peserta didik untuk mencatat hasil } \\
\text { diskusi serta kesimpulan. }\end{array}$ & $\begin{array}{l}\text { Mencatat hasil penjelasan dan } \\
\text { kesimpulan dari guru dan } \\
\text { diskusi kelompok }\end{array}$ \\
\hline Evaluation & \begin{tabular}{l|l} 
& - \\
penilaian proses \\
- & Menilai pengetahuan peserta didik \\
- & Memberikan balikan terhadap jawaban \\
peserta didik
\end{tabular} & $\begin{array}{l}\text { Menjawab pertanyaan } \\
\text { berdasarkan data } \\
\text { Mendemonstrasikan } \\
\text { kemampuan dalam } \\
\text { penguasaan konsep }\end{array}$ \\
\hline
\end{tabular}

Sumber: Nana, Surahman E.2019. Pengembangan Inovasi Pembelajaran Digital

Menggunakan Model Blended POE2WE di Era Revolusi Industri 4.0 Prosiding

SNFA (Seminar Nasional dan Aplikasinya), 82-90

\subsection{Model poe2we berbasis pendidikan karakter}

Nilai-nilai pendidikan karakter dapat diintegrasikan ke dalam proses pembelajaran, termasuk dalam pembelajaran fisika. Fisika menjelaskan berbagai gejala fisis fenomena yang terjadi di alam, baik secara teori maupun perhitungan. Hal ini mengindikasikan bahwa terdapat ruang-ruang dalam mata pelajaran fisika yang dapat dijadikan sebagai sarana dalam mengembangkan nilai-nilai pendidikan karakter pada diri siswa, asalkan pembelajaran fisika di dilaksanakan dengan sebagaimana mestinya (Diani., 2015)

Menurut Nana \& Endang Surahman (Nana, 2014, 2016; Nana et al., 2014; Permatasari, 2011; Rahayu et al., 2013; Samosir, 2010). Model pembelajaran $\mathrm{POE}_{2} \mathrm{WE}$ dapat menjadikan peserta didik sebagai subjek di dalam pembelajaran. peserta didik secara aktif menemukan suatu konsep melalui pengamatan atau eksperimen secara langsung, bukan dari menghafal buku materi maupun penjelasan dari guru. Model ini memungkinkan peserta didik aktif dalam proses pembelajaran, memberikan kesempatan kepada peserta didik untuk mengonstruksi pengetahuannya, mengkomunikasikan pemikirannya dan menuliskan hasil diskusinya sehingga peserta didik lebih menguasai dan memahami konsep yang akan berdampak pada peningkatan prestasi belajar peserta didik Model ini memberikan kesempatan kepada peserta didik untuk melakukan konstruksi pengetahuan yang dimilikinya, melakukan pengamatan terhadap fenomena serta mengkomunikasikan gagasan yang dia perolah dari proses diskusi sehingga peserta didik akan lebih mudah menguasai konsep yang diajarkan.

Sehingga, dengan model pembelajaran POE2WE, peserta didik tidak hanya menguasai teori ataupun konsep materi pembelajaran fisika, tetapi di tahap Elaboration peserta didik mampu mengambil pelajaran ataupun mengimplementasikan materi fisika tersebut dalam kehidupan sehari hari. Sehingga, tidak hanya meningkatkan kemampuan kognitif peserta didik, tetapi mampu meningkatkan pendidikan karakter peserta didik tersebut.

\section{KESIMPULAN}

Menurut Komara ( dalam Koesoema, 2007; Muslich, 2011; dan Zainal, 2011) Pendidikan karakter merupakan suatu keniscayaan dalam upaya menghadapi berbagai tantangan pergeseran karakter yang dihadapi saat ini. Pendidikan karakter bertujuan 
mengembangkan kemampuan seseorang untuk memberikan keputusan baik-buruk, memelihara apa yang baik, dan mewujudkan kebaikan itu dalam kehidupan sehari-hari dengan sepenuh hati.

Menurut Nana \& Endang Surahman (Nana et al. 2014)

Menurut Nana \& Endang Surahman (Nana et al., 2014) Model $\mathrm{POE}_{2} \mathrm{WE}$ merupakan model pembelajaran yang dikembangkan untuk mengetahui pemahaman peserta didik mengenai suatu konsep dengan pendekatan konstruktivistik.

Nilai-nilai pendidikan karakter dapat diintegrasikan ke dalam proses pembelajaran, termasuk dalam pembelajaran fisika. Fisika menjelaskan berbagai gejala fisis fenomena yang terjadi di alam, baik secara teori maupun perhitungan. Hal ini mengindikasikan bahwa terdapat ruang-ruang dalam mata pelajaran fisika yang dapat dijadikan sebagai sarana dalam mengembangkan nilai-nilai pendidikan karakter pada diri siswa, asalkan pembelajaran fisika di dilaksanakan dengan sebagaimana mestinya (Rahma Diani., 2015)

Sehingga, dengan model pembelajaran POE2WE, peserta didik tidak hanya menguasai teori ataupun konsep materi pembelajaran fisika, tetapi di tahap Elaboration peserta didik mampu mengambil pelajaran ataupun mengimplementasikan materi fisika tersebut dalam kehidupan sehari hari. Sehingga, tidak hanya meningkatkan kemampuan kognitif peserta didik, tetapi mampu meningkatkan pendidikan karakter peserta didik tersebut

\section{UCAPAN TERIMAKASIH}

Ucapan terima kasih saya panjatkan kepada berbagai pihak yang telah membantu dan membimbing saya selama penyusunan jurnal ini, terutama kepada dosen mata kuliah Fisika Sekolah II \& Evaluasi Pembelajaran Fisika yaitu Dr. Nana., M.Pd. yang telah membimbing saya dalam penyusunan jurnal ini. $।$

\section{REFERENSI}

Diani, Rahmi. (2015). PENGEMBANGAN PERANGKAT PEMBELAJARAN FISIKA BERBASIS PENDIDIKAN KARAKTER DENGAN MODEL PROBLEM BASED INSTRUCTION. Jurnal Ilmiah Pendidikan Fisika Al-BiRuNi. 04(02), 243.

Duffy, T. M., \& Jonassen, D. H. (1992). Constructivism and the technology of instruction: A conversation. Hillsdale, New Jersey Hove, London: Lawrence Earlbaum Associates.

Indra. (2011). Dibeberkan, Parahnya Kecurangan UN SMA, artikel di website: http://edukasi.kompas.com/read/2011/04/25/19171563/Dibeberkan.Parahnya.Kecura ngan.UN.SMA. [28 Februari 2012].

Komara, Endang. (2018). Penguatan Pendidikan Karakter dan Pembelajaran Abad 21. SIPATAHOENAN: South-East Asian Journal for Youth, Sports \& Healt Education. 4(1), 18-24.

Nana. (2014). Pengembangan model POE2WE dalam pembelajaran Fisika SMA. Universitas Sebelas Maret.

Nana \& Endang Surahman. (2019). Pengembangan Inovasi Pembelajaran Digital Menggunakan Model Blended $\mathrm{POE}_{2}$ WE di Era Revolusi Industri 4.0.

Prosiding SNFA (Seminar Nasional Fisika dan Aplikasinya) 2019. 84-87

Pulungan, Fatma Reni. (2012). PENGARUHMODEL PEMBELAJARAN PROBLEM BASED LEARNING BERBASIS PENDIDIKAN KARAKTER TERHADAP 
PERUBAHAN KARAKTER DAN KEMAMPUAN MENYELESAIKAN MASALAH FISIKA. Jurnal Penelitian Pendidikan Fisika. 4(2), 38-42.

Samosir, H. (2010). Model Pembelajaran Predict-Observe-Explain-Write (POEW) untuk meningkatkan penguasaan konsep kalor dan keterampilan berpikir kritis siswa SMA. Universitas Pendidikan Indonesia.

Zuchdi, Darmiyati., Anik Ghufron.,Kastam Syamsi., \& Muhsinatun Siasah Masruri. (2014). PEMETAAN IMPLEMENTASI PENDIDIKAN KARAKTER

DI SD, SMP, DAN SMA DI KOTA YOGYAKARTA. Jurnal Pendidikan Karakter. IV (1), 3-6. 